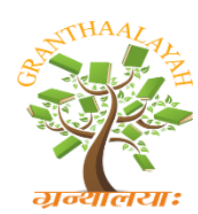
\author{
GRANTHAALAYAH \\ A knowledge Repository
}

INTERNATIONAL JOURNAL OF RESEARCH -

Social

\title{
RAMESHWARI NEHRU AND THE CAUSE OF INDIAN WOMEN
}

\author{
Roshani Rai ${ }^{* 1}$ \\ ${ }^{* 1}$ Assistant Professor, Tripura University, Agartala, India
}

DOI: https://doi.org/10.29121/granthaalayah.v5.i6.2017.2055

\begin{abstract}
Rameshwari Nehru came from a very orthodox family where purdah system was observed very strictly. Having been denied formal education, however Rameshwari Nehru was able to make a deep mark in the pages of history by her relentless efforts to bring about the emancipation of women in the society. In this respect her journal Stree Darpan played a notable role. This paper is a humble attempt to narrate the activities of Rameshwari Nehru for the cause of Indian women.
\end{abstract}

Keywords: Rameshwari Nehru; Purdah; Emancipation; Stree Darpan.

Cite This Article: Roshani Rai. (2017). "RAMESHWARI NEHRU AND THE CAUSE OF INDIAN WOMEN." International Journal of Research - Granthaalayah, 5(6), 453-457. https://doi.org/10.29121/granthaalayah.v5.i6.2017.2055.

\section{Introduction}

Rameshwari Nehru, Mataji as she was popularly known as, was a remarkable woman who played a significant role in the awakening of women in the early decade of the twentieth century. She has left an indelible mark in the history of the women's movement in India. This paper attempts to narrate the efforts undertaken by Rameshwari Nehru to work for the cause of the women of India.

Rameshwari Nehru was born on $10^{\text {th }}$ December, 1889. She along with her three sisters and one brother lived a very luxurious life at the large ancestral Haveli in Lahore which had been bestowed to her grandfather Dewan Ajodhya Prasad by Maharaja Ranjit Singh of Punjab. Though born in a high class, aristocratic family, Rameshwari Nehru and her sisters were denied formal education. Her father Raja Narendra Nath, although highly educated and intelligent, was orthodox in nature and enforced the rules of segregation of boys and girls very rigidly and gave high regard to the purdah system.

However, Rameshwari managed to get education from the governess, whom her father had appointed for his son Anand Kumar at home. Thus Rameshwari Nehru received her education at 
home. She strongly disagreed to her father's remark: "A woman must be a good cook and should never let the bread burn on the tawa" which did not appeal to her at all. Subsequently, it can be seen that Rameshwari became a fierce champion of women's legitimate rights and their status in the society. ${ }^{1}$ Moreover as a child, Rameshwari always dreamt of India's independence inspite of her restricted exposure to developments of fresh patriotic movements outside in the country. ${ }^{2}$

Rameshwari Nehru was married in December 1902 to Brijlal Nehru, who was the youngest son of Motilal Nehru's elder brother Nandlal Nehru. When Nandlal died, Motilal Nehru had taken the full responsibility of looking after the children of his brother. He showered his affection on his son Jawaharlal and nephew Brijlal in equal measure. He sent both of them to England for higher studies. When Brijlal was in London, Motilal wrote him a letter wanting Rameshwari to have an opportunity to live with Brijlal in England so that she could widen her knowledge of the world.

The Westernized outlook and liberal environment of 'Anand Bhawan'3 appealed to Rameshwari very much as she got a favourable opportunity to express her liberal ideas and free thinking through the medium of her choice and this was how her patriotic and feminist outlook gained strength and conviction. There were no conservative constraints and restrictions, no purdah system among women and under Motilal's liberating influence, she discarded purdah. As a part of her emancipator drive, she persuaded women of her natal family in Lahore to discard purdah. ${ }^{4}$

By and large, it can be seen that it was from Anand Bhawan that Rameshwari Nehru started her eventful career which was dedicated for the cause of the women, the Harijans and the Indian freedom struggle. The liberal Westernized atmosphere of Anand Bhawan enabled her to enrich her social vision and formulate progressive views on women's role in home, society and polity. ${ }^{5}$ She was of the opinion that Indian womanhood would attain full stature only if the Indian women were emancipated.

Earlier in the nineteenth century, the reform movement leaders who took up the women's cause came from the enlightened male section and not from the women themselves. They made some stray efforts to bring some reforms like abolition of sati, widow remarriage etc. "But gradually the women's movement became dynamic when the Indian woman's cause was championed by the women themselves. Their conferences were no longer meetings of a few enlightened and advanced reformers but mammoth meetings attended by thousands of women coming from every strata of society. The decisions of women's conferences held under the leadership of Indian women, found ardent and enthusiastic champions among the legislators........ Among these talented Indian women who took a prominent part in bringing about this great change in the public opinion Mrs. Rameshwari Nehru is one of the foremost....."6

Rameshwari Nehru was of the view that: "Unlike men, women were burdened with social, legal and customary disabilities such as denial of right to life, purdah, child marriage, widowhood, pro-male inheritance and guardianship laws, denial of education and citizenship rights. Owing to the faulty construction of society, women continued to be denied economic security and a dignified life despite perpetual reminders regarding women's proper place in homes. In short women have never been given equal rights in law or in practice."7 Therefore for Rameshwari Nehru the women's movement stood for full equality of woman with man in all spheres of life 
and her complete emancipation from the legal and customary disabilities inflicted on her during the present times.

Rameshwari Nehru started the first women's journal in Hindi called Stree Darpan in 1909 from Allahabad. It was through Stree Darpan that she emphasized on women's rights and argued for reforms in gender relations. ${ }^{8}$ Therefore she was able to inspire and motivate a number of educated and socially committed women to work for reducing gender discrimination and oppression and to combine their roles as mothers and wives with participation in public life. ${ }^{9}$ Since Rameshwari Nehru also became active member of the Women's India Association and All India Women's Conference, she received further support of the institutional networks and resources of women's organizations for furthering her relentless crusade for Indian women's rights. ${ }^{10}$

Rameshwari Nehru's strongly supported the political enfranchisement of Indian women. She was of the view that "the Indian women desired the vote not from a sense of self-aggrandizement but to fulfill their duties and responsibilities in public life."11 Through her various editorials in her journal Stree Darpan, she was able to make the readers familiar with the significance of the right to vote to women and the opposition of the orthodox leaders. She played an important role to mobilize public opinion in favour of women's enfranchisement. She was concerned for the voting rights of women, since the 'wifehood' and 'property' criteria as eligibility to vote which had been added by the British was bound to disenfranchise the women voters even after independence. Therefore she is said to have written to Prime Minister Jawaharlal Nehru for revising the electoral rolls, based on 'wifehood' and property qualifications in order to make larger number of women eligible as voters. Ultimately the dream of political enfranchisement of women was fulfilled after a long drawn struggle by the women.

Rameshwari Nehru was also equally concerned for the prostitutes who were the most oppressed and exploited group of women. She had been deeply moved by the plight of the devdasis in the temples of Mysore. She wanted an organized effort to solve this problem. She therefore organized the Association for Moral and Social Hygiene, the Indian counterpart of the Abolitionists Federation at the international level and she served as President of the organization from the start. ${ }^{12}$ She had also started a Nari Niketan to help women in moral danger or to rehabilitate those rescued from brothels.

Rameshwari Nehru also set up the Mahila Samiti for training women workers and inspires women not only to fight for their own rights and for equality of status of women with men, but also fight shoulder to shoulder with men in the country's freedom struggle. Linking women's movement with the country's freedom at a larger perspective she wrote: "India at present is engaged in her fight for freedom which means life and death for her. At this time of her need, she cannot afford to neglect any section of her people, however insignificant. The awakening of women means redoubled reinforcements of her resources. The fear that other activities besides the political may divert attention from the real issues and thus weaken them is not right. Swaraj cannot be attained by people whose other halves are stricken paralysis. The process of curing that paralysis, of shaking the sleepy partner out of her inertia, of infusing life into her, cannot but bring strength to the whole nation. The battle of Swaraj has to be fought and won by men and women alike...."13 
Rameshwari Nehru raised a strong voice of protest against the evil practice of child marriage through publications of number of articles in daily newspapers and periodicals and symposia proceedings. For instance she contributed her article entitled 'Early Marriage' to the symposium proceedings Our Cause, edited by Shyama Kumari Nehru. When the British Government appointed the Age of Consent Committee in 1928 to fix the consent for girls, Rameshwari Nehru was the only woman invited to serve on it and did so with distinction. She was the only Indian woman member of the Committee. She contributed a long note on the plight of child wives, which was incorporated in the report of the Committee. This report formed the groundwork for the Child Marriage Restraint Act which was later enacted. ${ }^{14}$

Besides her activities at home, Rameshwari Nehru also actively highlighted the cause of Indian women abroad. In the early 1930s she went to England as a prominent representative of the women in India where she addressed meetings which was attended by both Indian and British women. As a champion of Indian women, she was elected on the Presidium of a meeting in London on April 201931 as Chairman of the Committee of the Women's Committee of the Commonwealth of India League. She therefore toured many countries in the Continent mobilizing sympathy for the cause of India and Indian women.

Following the partition of the country, India was faced with a gigantic task of rehabilitation of refugees in India. Rameshwari Nehru, as Honorary Advisor to the Ministry of Rehabilitation played a very important role in the restoration of abducted women and children. She devoted all her energy in helping the suffering people and particularly took special pains to help the women, orphans, children and Harijan families. Under her direction several centers were created for women and children to serve their needs. She played a very significant role in the rehabilitation of the refugees and particularly she became a source of comfort to helpless women and families of all communities. In 1955 the Government of India honored Rameshwari Nehru by awarding Padma Bhushan for her outstanding contributions in the field of rehabilitation of refugees specially widows, orphans, children and old people. ${ }^{15}$

Therefore it can be seen that Rameshwari Nehru committed her life for the well-being and emancipation of the women folk. Being brought up under orthodox environment, later after marriage she got opportunities to move along with the changing times politically and socially under the liberal atmosphere of Anand Bhawan, from where she started her eventful career as women rights activists, as a freedom fighter. Therefore Rameshwari Nehru's contributions for the emancipation of women constitute an important chapter in the history of women's movement in India. Vijaya Lakshmi Pandit aptly pointed out: "She had a long and fruitful life and left behind memory that will always inspire others."16

\section{References}

[1] Om Prakash Paliwal. Rameshwari Nehru. New Delhi: National Book Trust; 1986, pp. 3-4.

[2] Ibid, p.5.

[3] Anand Bhawan meaning "Abode of Happiness" was built by Motilal Nehru in 1899.

[4] Kamlesh Mohan. Rameshwari Nehru. New Delhi: National Book Trust; 2013, p. 12.

[5] Kamlesh Mohan. Towards Gender History: Images, Identities and Roles of North Indian Women. Delhi: Aakar Books; 2007, p.107.

[6] Quoted in Om Prakash Paliwal, op.cit., p.14. 
[7] Kamlesh Mohan, op. cit., pp. 84-85

[8] Suruchi Thapar Bjorkert. Women in the Indian National Movement: Unseen Faces and Unheard Voices 1930-42. New Delhi: Sage Publications; 2006, p.219.

[9] Kamlesh Mohan, op.cit., 77

[10] Ibid, p.97.

[11] Cited in Kamlesh Mohan, op.cit., p. 93

[12] Sushila Nayyar, "Mata Rameshwari Nehru" in Sushila Nayyar and Kamla Mankekar (Ed).Women Pioneers in Indian Renaissance. New Delhi: National Book Trust; 2007, p.255.

[13] Cited in Om Prakash Paliwal, op.cit., p.19.

[14] Sushila Nayyar, op.cit., p. 258.

[15] Om Prakash Paliwal, op.cit., p. 47.

[16] Vijaya Lakshmi Pandit. (1979). The Scope of Happiness. London: Widenfeld and Nicolson; 1979, p. 31.

*Corresponding author.

E-mail address: rai_rosh@yahoo.co.in 